\title{
GENURILE SANGUISORBA L. ȘI POTERIUM L. (ROSACEAE ADANS.) ÎN REPUBLICA MOLDOVA
}

\author{
Elena TOFAN-DOROFEEV \\ Grădina Botanică Națională (Institut) „,Al. Ciubotaru”, \\ Chișinău, Republica Moldova
}

\begin{abstract}
The morphological differences of the genera Sanguisorba and Poterium have been described and they allow us to treat them as distinct taxonomic units.

Key words: Sanguisorba, Poterium, genus, morphological features.
\end{abstract}

Genul Sanguisorba L. (subtribul Sanguisorbinae, tribul Sanguisorbeae, subfamilia Rosoideae, familia Rosaceae) include circa 27 de specii răspândite preponderent în zonele temperate și în regiunea sub-arctică a emisferei nordice [3]. Genurile Sanguisorba L. și Poterium L. au fost descrise pentru prima dată de către Linnaeus (1753), ca genuri distincte, însă ulterior aceste două genuri au fost concentrate într-un singur gen sub numele de Sanguisorba (Bertoloni, 1835; Brown și Bouche, 1867; Nordborg, 1966) sau Poterium (Spach, 1846; Bentham și Hooker, 1865). De atunci, au existat multe alte modificări taxonomice ale genului.

Prelucrarea critică a subfamiliei Rosoideae în cadrul pregătirii pentru editare a monografiei „Flora Basarabiei”, examinarea profundă a lucrărilor de domeniu, analiza critică a exsicatelor păstrate în herbare, ne-a permis să concluzionăm că amplasarea unităţilor taxonomice Poterium și Sanguisorba în același gen, sugerată de unii botaniști, este nejustificată. Statutul genurilor, inclusiv al speciilor acestor două genuri, a fost un subiect permanent de discuție. Botaniști precum Proctor și Nordborg (1968); Buia (1956); Takhtajan (1997); Kalkman (2004); Ciocârlan (2009) percep genul Sanguisorba L. sensu lato, incluzând aici și Poterium. Alții, ca Yuzepchuk (1941), Hutchinson (1964), Kamelin (2001), Potter et al. (2007) recunosc aceste genuri ca fiind independente. Inclusiv în Republica Moldova există diferite opinii cu privire la acest subiect. Gheideman $(1975,1986)$ precum și Negru (2007) prezintă genurile Sanguisorba și Poterium separat, cu speciile: Sanguisorba officinalis L., Poterium sanguisorba L. și Poterium poligamum Waldst. et Kit., iar Pînzaru și Sîrbu (2016) percep genul Sanguisorba L. sensu lato.

Ultimile studii filogenetice moleculare sugerează că Sanguisorba sensu stricto este o linie distinctă de Poterium și acestea au evoluat independent în linii filogenetice diferite [1]. Ne alăturăm punctului de vedere al lui Kamelin expus în Flora Europei Orientale [3] cu privire la interpretarea separată a acestor două genuri, cu atât mai mult cu cât și ultimile date privind morfologia polenului confirmă cele spuse de acesta [2].

În opinia noastră, diferențele morfologice dintre genurile Sanguisorba și Poterium sunt semnificative și anume:

- Plante cu flori numai bisexuate; tepale petaloide roșii-brunii; stamine 4, neexserte sau subegale cu periantul; gineceu unicarpelar, ovar cu 1 stil terminal; polen 6-colporat

- Plante poligame; tepale petaloide verzui; stamine 20-30, evident exserte; ovar cu 
două stile; polen 3-colporat Poterium

Speciile genului Sanguisorba L. sunt plante erbacee, perene, cu flori hermafrodite, grupate în inflorescenţe dense, terminale, capituliforme sau spiciforme. Hipantiu cupulifer. Caliciul propriu-zis lipsă. Tepalele periantului 4, petaloide, roşii-bordo. Stamine 4, roșii, subegale cu periantul. Gineceu 1-carpelar, ovar inferior, stil terminal, stigmat dilatat, papilos. Fruct - nuculă, închisă în totalitate în receptaculul 4-muchiat.

Genul Poterium L. cuprinde plante erbacee, perene, cu flori adunate în inflorescenţe poligame capituliforme, dense, scurt cilindrice sau globuloase, terminale. În cadrul inflorescenţei florile inferioare sunt mascule, cele mijlocii hermafrodite, iar cele superioare femele, fiecare cu o bractee şi 2 bracteole. Hipantiu urceolat. Tepalele periantului 4, verzi sau verzi-gălbui, mai târziu brunii. Stamine 20-30, evident exserte din periant. Carpele 2, ovar inferior cu 2 stile şi stigmate fimbriate, roşu-purpurii. Fruct cu 2 semințe, fiecare sămânță cu propria tunică și ambele închise în receptaculul tetramuchiat, reticulat-rugos sau alveolat.

Desigur, aceste două genuri sunt foarte apropiate, și totuși, speciile acestor genuri prezintă caractere morfologice distinctive, suficient de evidente și importante la nivelul organelor generative (numărul de stamine și de carpele, precum și diferențe în structura polenului) mult mai valoroase și constante decât diferențele la nivelul organelor vegetative, care sunt folosite adesea pentru diferențierea lor.

Cercetările au fost realizate cu suportul ANCD în cadrul proiectului „Cercetarea și conservarea florei vasculare și macromicobiotei din Republica Moldova”, cifrul 20.80009.7007.22 (contract de finanțare Nr. 71/PS/2020).

\section{BIBLIOGRAFIE}

1. Potter D., Eriksson T. et al. Phylogeny and classification of Rosaceae. Plant Systematics and Evolution, 2007. V. 266, p. 5-43.

2. Lee S., Heo K., Cho J. et al. New insights into pollen morphology and its implications in the phylogeny of Sanguisorba L. (Rosaceae; Sanguisorbeae). Plant Systematics and Evolution, 2011. V. 291, p. 227-242.

3. Камелин Р. Род Sanguisorba L. и Poterium L. В: Флора Восточной Европы. Санкт-Петербург: Мир и Семья, 2001, с. 532-535. 